\title{
Comparison of Language Ability and Speech Production BetweenConstraint Induced Aphasia Therapy and Standard Speech Therapy for Chronic Broca Aphasian After Stroke
}

\author{
Dian Kusumawati, Ratna D Haryadi \\ Department of Physical Medicine and Rehabilitation Faculty of Airlangga University - Dr. Soetomo \\ Hospital, Surabaya - Indonesia
}

\begin{abstract}
Objectives : The objective of this research is to determine an effective speech theraphy methods on post stroke patient with chronic aphasia Broca

Methods : A randomized controlled trial involeved fourteen patients with Broca's Aphasia post stroke that divided into 2 groups : Group I -7 patients underwent 2 weekly sessions of Constraint Induced Aphasia Therapy (CIAT), 5 times a week, one hour for each session. Group II - 7 patients underwent 3 weekly sessions of standard method speech therapy, 3 times weekly and one hour for each session upto 10 hours. All patients were examined using Communicative Activity Log (CAL) to evaluate language ability and Functional Independence Measurement (FIM), expression communication's subtest to evaluate speech production. CAL and FIM were performed pre and post therapy sessions.

Results : Language ability and speech production were are increasing after CIAT $(p=0,015)$ and also in group of standard methods of speech therapy as well $(\mathrm{p}=0,016)$.

Conclusions : CIAT and standard speech therapy methods isgnificantly increase language ability and speech production in stroke patients with chronic Broca aphasia.
\end{abstract}

Keywords : Constraint Induced Aphasia Therapy (CIAT), standard speech therapy methods, Broca's Aphasia post stroke.

\section{INTRODUCTION}

Language function is one of the most important component in high brain function, because human specific ability is his ability to put his mind and feeling through the function of speech and language. Modality of language may be through verbal, graphic (hand writing or other visual symbols), and gesture (mimic, pantomimic, and

Received in March 2012 and accepted for published in April 2012.

Correspondence address : Dian Kusumawati, RSIA Hermina Podomoro J1. Danau Agung 2 blok E3 no 28-30. Jakarta Utara, Indonesia ; Email: diansprm@ gmail.com body gesture). Language has receptive function (language is useful to understand and to interpret various stimuli accepted and translated into a concept), and expressive function (language is useful to express mind, feeling, and desires through understandable symbols). ${ }^{1,2,3,4}$

Aphasia is defined as language disorder which is caused by the damage of the brain. Most common cause of aphasia is stroke $(85 \%)$, followed by brain injury, brain tumor, and degenerative diseases (15\%). ${ }^{5,6,7,8,9,10}$ Data of the incidence of aphasia in USA is very limited, about $20 \%$ of stroke patients will suffer from aphasia. More than 700,000 stroke cases happens every year, and it is assumed to be 170,000 new cases of aphasia per year.7 In Indonesia, there is no data of incidence of stroke 
and aphasia. Whilst in Surabaya, incidence of stroke in 1996 is about 1400 new stroke patients from 5 governmental and private hospitals, from about 2.3 million citizens; also there is a tendency of increasing number of cases from year to year. ${ }^{11}$

The limitation of communication in aphasia may cause patients with chronic aphasia unable to do their previous occupation and may also limit their social living. This may cause several problems in individuals as well as financial problems. ${ }^{7,8}$

The methods of speech therapy in aphasia are keep developing. Study to obtain accurate data of the effectivity of new speech therapy compared with the available speech therapy is needed. This study aims to compare the effectivity of standard speech therapy with the method of Constraint Induced Aphasia Therapy (CIAT) to improve language ability and language production in post stroke individuals with chronic Broca aphasia.

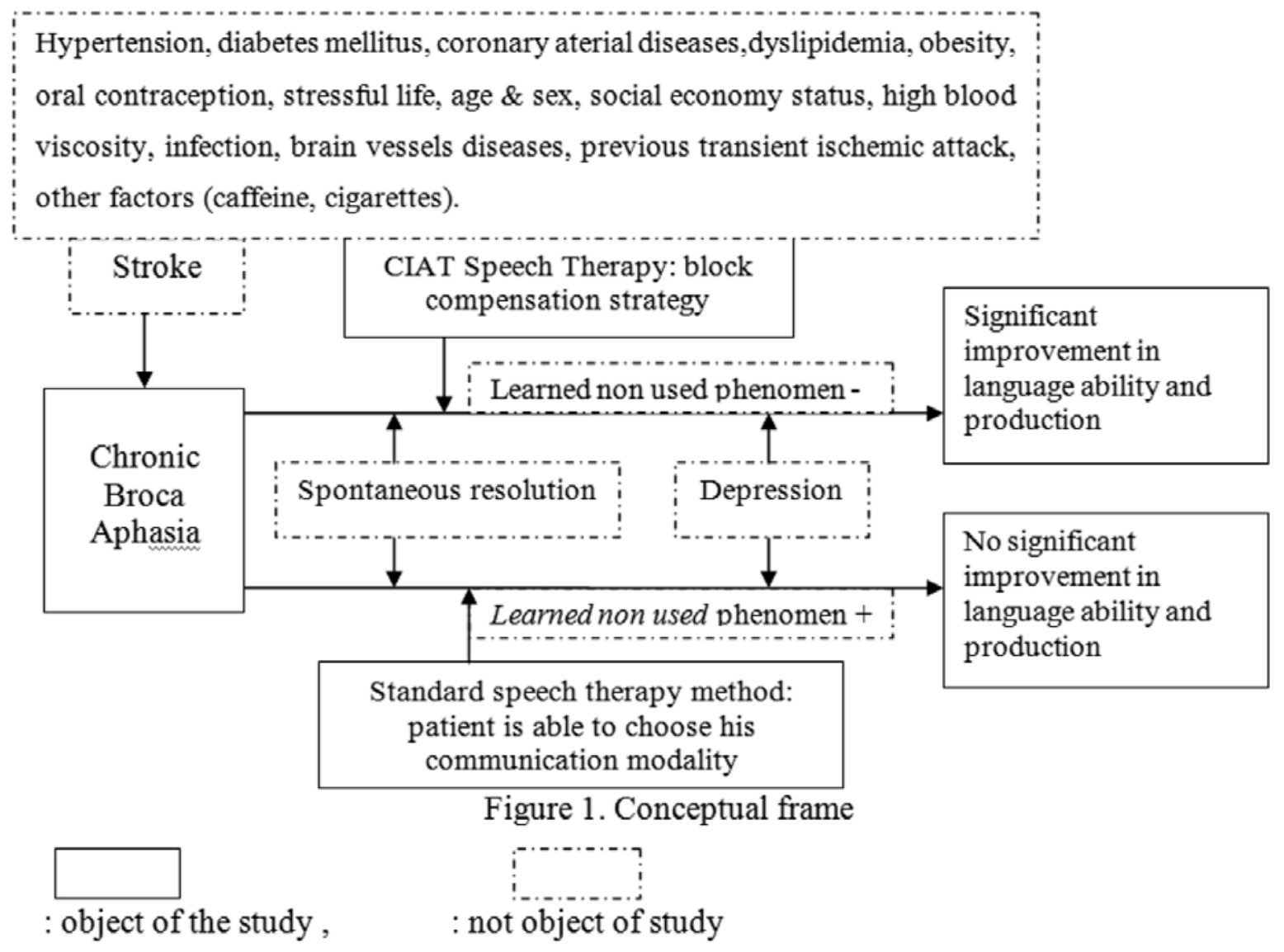

Details of conceptual frame:

Stroke is caused by various risk factors. Stroke causes the most of aphasia cases, one of which is Broca aphasia. Resolution of the Broca aphasia can be measured by the increase of language ability and language production. This resolution is influenced by several variables, such as the speech therapy method, depression state, and also the spontaneous resolution of the aphasia.

In CIAT speech therapy method, blockage of compensation strategy prevents the learned non used phenomen, which is able to increase the ability and production of speech significantly. The standard speech therapy method free the communication way that can be used by individuals, which cause the learned non used phenomen to be positive, so the ability and production of speech become not significantly improved.

The study hypotesis is that CIAT speech therapy method is better than the standard speech therapy method to increase the language ability and language production in the post stroke chronic Broca aphasia individuals. 


\section{METHODS}

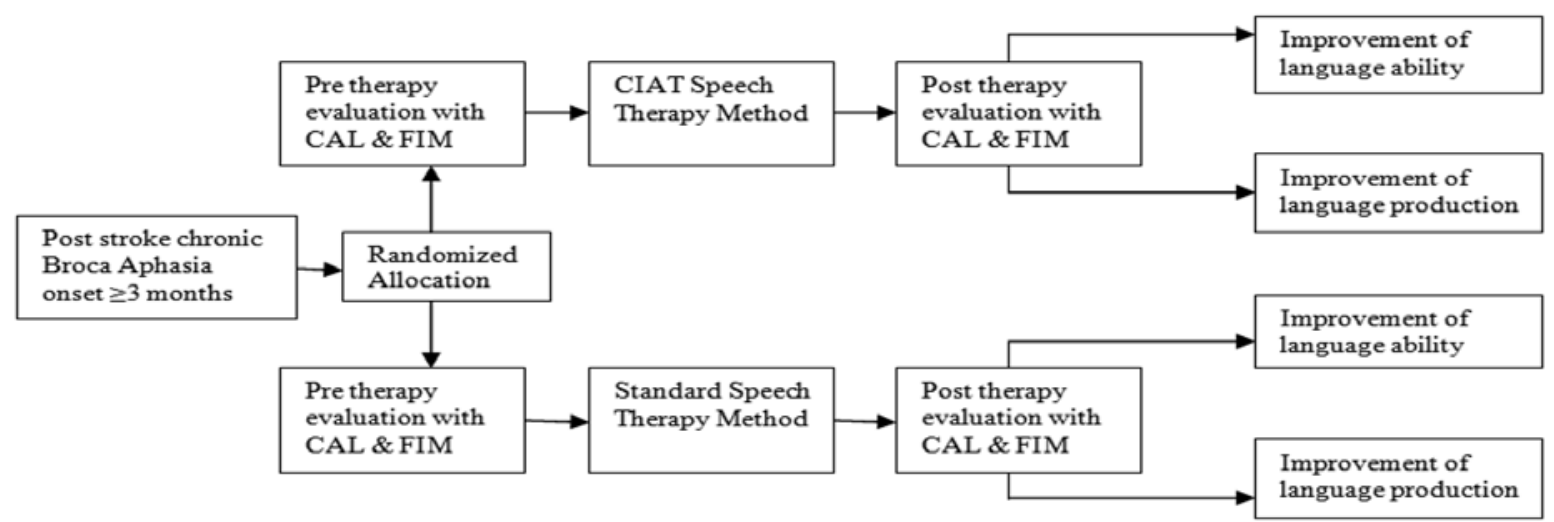

Figure 2. Study Design

This is a randomized clinical trial study. Study subjects who fit the inclusion criteria were taken by consecutive sampling technique, randomized alocation was done by using randomized table to meet the needed 14 study subjects. Subjects were divided into two groups of therapy, the CIAT speech therapy group and standard speech therapy group. Pre and post therapy evaluation were done before and after the speech therapy by using the Communicative Activity Log (CAL) and Functional Independence Measurement (FIM), to figure out the increase of language ability and language production.

The inclusion criteria are those individuals with Broca aphasia (diagnosis was done using the Tes Afasia untuk Diagnosis, Informasi, Rehabilitasi atau TADIR), post stroke for minimal 3 months duration, use Indonesian language as their mother tongue, age ranges from 40 to 60 years, and willing to participate in this study by signing informed consent. Exclusion criteria are uncontrolled hypertension, cardiorespiration disorders, moderate to severe depression on assessment with Beck Questionnaire, and apraxia. Drop out criteria are if the subject died or did not come for therapy session fot two consecutive session in a week.

\section{RESULTS}

This study focused on two groups of subjects with post stroke chronic Broca aphasia, whose stroke duration minimal 3 months, use
Indonesian language as their mother tongue, age 40 to 60 years old, and have signed the informed consent. Each group comprises of 7 subjects. The first group received speech therapy with the Constraint Induced Aphasia Therapy (CIAT) method, 5 times a week, for 2 weeks. The second group received standard speech therapy, 3 times a week until 10 therapy sessions; both groups has 1 hour duration for each therapy session. The first group are named as the CIAT method group and the second group as the standard method group.

Assessment of language ability and language production pre and post speech therapy were taken to every study subjects. The language ability assessment was done by the Communicative Activity Log (CAL) instrument, while the language production was done by the Functional Independence Measurement (FIM) instrument on the expression communication subtest. One subject from the CIAT speech therapy group was drop out, due to his inability to undergo speech therapy for two consecutive sessions in a week.

Test of normality of data was done by the Kolmogorov-Smirnov statistical test. Comparisons between language ability and language production pre and post therapy to both groups was done by t-Independent 2 Sample Test for data with normal distribution, and Mann-Whitney test for abnormal distribution data. To know the difference of language ability and language production pre and post therapy for both groups, paired t-test was done for 
normal distribution data, and Wilcoxon Signed Ranks Test was done for abnormal distribution dat. Significance level $(\alpha)$ is $0.05(5 \%)$, that the $\mathrm{p}$ value is considered significant if $\mathrm{p}$ value $<$ 0.05 and not significant if $p$ value $\geq 0.05$.

Table 1. Normality test of the CIAT method therapy group

\begin{tabular}{lllll}
\hline & Mean & SD & P & Significance \\
\hline CAL pre therapy & 36.71 & 10.012 & 0.200 & Not significant \\
CAL post therapy & 54.29 & 8.826 & 0.062 & Not significant \\
Comparison of CAL improvement & 17.57 & 7.020 & 0.200 & Not significant \\
\hline
\end{tabular}

Table 1 shows the result of normality test for the CIAT method therapy group. Normality test pre and post treatment and comparisons of the improvement of CAL with $\mathrm{p}$ value $\geq 0.05$ show that the data has normal distribution.

Table 2. Normality test of the standard method therapy group

\begin{tabular}{lllll}
\hline & Mean & SD & P & Significance \\
\hline CAL pre therapy & 37.57 & 10.277 & 0.174 & Not significant \\
CAL post therapy & 52.00 & 9.292 & 0.200 & Not significant \\
Comparison of CAL improvement & 14.43 & 11.516 & 0.200 & Not significant \\
\hline
\end{tabular}

Table 2 shows the result of normality test for the standard method therapy group. Normality test pre and post treatment and comparisons of the improvement of CAL with $\mathrm{p}$ value $\geq 0.05$ show that the data has normal distribution.

Comparisons of language ability pre and post therapy, and its improvement between the
CIAT method group and the standard method group were analyzed by using t-Independent 2 Sample Test. The comparisons of language ability pre and post speech therapy, and its improvement between the CIAT method group and the standard method group shows no significant difference between both groups (see table 3).

Table 3. Analysis of comparisons of language ability between CIAT method group and standard method group

\begin{tabular}{lcllll}
\hline & Speech Therapy Method & Mean & SD & P & Significance \\
\hline CAL pre therapy & CIAT & 36.71 & 10.012 & 0.877 & Not significant \\
& Standard & 37.57 & 10277 & & \\
CAL post therapy & CIAT & 54.29 & 8.826 & 0.645 & Not significant \\
& Standard & 52.00 & 9.292 & & \\
Comparison of CAL improvement & CIAT & 17.57 & 7.020 & 0.551 & Not significant \\
& Standard & 14.43 & 11.516 & & \\
\hline
\end{tabular}

Comparisons of language production pre and post therapy, and its improvement of language production between the CIAT method group and the standard method group were analyzed by using Mann-Whitney test. The comparisons of language production pre and post therapy, and its improvement of language production shows no significant difference between both groups (see table 4). 
Table 4. Analysis of Comparisons of Language Production between CIAT Method Group and Standard Method Group

\begin{tabular}{lcllc}
\hline & Speech Therapy Method & Mean & P & Significance \\
\hline CAL pre therapy & CIAT & 7.50 & 1 & Not significant \\
& Standard & 7.50 & & \\
CAL post therapy & CIAT & 8.50 & 0.254 & Not significant \\
& Standard & 8.50 & & Not significant \\
Comparison of CAL improvement & CIAT & 1.00 & 0.383 & \\
& Standard & 0.50 & & \\
\hline
\end{tabular}

Comparisons of language ability pre and post therapy for each group were analyzed with paired t-test. There was significant difference of language ability pre and post therapy between the CIAT method group and the standard method group (see table 5).

Table 5. Analysis of comparisons of language ability for each group

\begin{tabular}{clllllll}
\hline & \multicolumn{2}{c}{ CAL pre therapy } & \multicolumn{2}{c}{ CAL post therapy } & \multirow{2}{*}{ Significance } \\
\cline { 2 - 5 } & Mean & SD & Mean & SD & & & Significant \\
CIAT Group & 36.71 & 10.012 & 54.29 & 8.826 & 0.001 & Signn \\
Standard Group & 37.57 & 10.277 & 52.00 & 9.292 & 0.016 & Significant \\
\hline
\end{tabular}

Comparisons of language production pre and post therapy for each group were analyzed with Wilcoxon Signed Ranks Test. There was significant difference of language production pre and post therapy between the CIAT method group and the standard method group (see table 6).

Table 6. Analysis of comparisons of language production for each group

\begin{tabular}{cccc}
\hline & Mean Level & $\mathrm{p}$ & Significance \\
\hline CIAT Group (FIM pre - post therapy) & 4.00 & 0.015 & Significant \\
Standard Group (FIM pre - post therapy) & 3.50 & 0.024 & Significant \\
\hline
\end{tabular}

\section{DISCUSSIONS}

Total subjects of this study were 14 subjects. To obtain general characteristics of this study, subjects, descriptive analysis of basic data of the whole study groups was done.

Mean age of study subjects from the Constraint Induced Aphasia Therapy (CIAT) method group was 56.285 years old with standard deviation 4.923 years. Youngest age of this group was 45 years old, the highest was 60 years old. Mean age of subjects from the standard method group was 52.285 years old with standard deviation 5.090 years. The youngest and the highest age of subjects from the standard group were the same as the CIAT group. T-test showed that mean age of subjects from both groups was not statistically different.

Educational level of subjects form both groups were from elementary school (SD) to high school (SMU), with the elementary school level as the most educational level, both in CIAT method group and in the standard method group. There was no significant difference of educational level characteristic of subjects from both groups.

Total male and female subjects from both groups were the same. The CIAT group consists of 3 males and 4 females, while the standard group consists of 4 males and 3 females subjects. There was no significant difference between sex characteristic of subjects ftom both groups.

In the normality test of language ability of both groups by the Kolmogorov-Smirnov statistical test, $\mathrm{p}$ value was $\geq 0.05$, which means that the data has normal distribution. Data with normal distribution can be analyzed by parametric test. Normal distribution also 
means that the data has normal dispersion and considered as able to represent the population.

The comparison of language ability pre therapy between the CIAT method group and standard method group was analyzed by t-Independent 2 Sample Test with $\mathrm{p}$ value $\geq$ 0.05 . This means that there was no significant diference of language ability pre therapy between both groups, that the language ability pre therapy of both groups were considered similar.

The comparison of language production pre therapy between the CIAT method group and standard method group was analyzed by Mann-Whitney Test with $p$ value $\geq 0.05$. This means that there was no significant diference of language production pre therapy between both groups, that the language ability pre therapy of both groups were considered similar.

The comparisons of language ability (by t-Independent 2 Sample Test) and language production (by Mann-Whitney test) post therapy between the CIAT method group and standard method group have gained $p$ value of $\geq 0.05$, which means that there were no significant difference of language ability and language production of both groups post therapy. This means that speech therapy with CIAT method and standard method were able to gain similar language ability and language production.

Maher et al39 in 2006 compared the ability of story telling pre and post therapy between the CIAT method and the Promoting Aphasic Communicative Effectiveness (PACE) method of 9 patients with post stroke chronic aphasia. Both speech therapies were done 4 times per week for 2 weeks with 3 hours duration for each therapy session. Maher found that the story telling ability was better with the CIAT method compared to the PACE speech therapy. The ability to report an event is considered as the ability of story telling, one of 18 items assessed in the Communicative Activity Log (CAL) instrument used to measure the language ability in this study. In this study, CAL is measured as a whole. The difference of observed variables can be the cause of difference of study results of Maher and this study.

The researcher obtained significant results $(p<0.05)$ from the analysis by paired $t$-test for the improvement of language ability as well as in the Wilcoxon Signed Ranks Test for language production post treatment, both from the CIAT method and standard method groups. This showed that both CIAT method and standard method are good or equal to increase the language ability and language production significantly of post stroke chronic aphasia subjects.

The result from the study by Pulvemuller et al32 was different with the result from this study. Pulvemuller et al in 2001 compared 17 chronic aphasia subjects of German native speaker. The CIAT method group $(\mathrm{n}=10)$ received therapy schedule $5 \mathrm{x} /$ week for 2 weeks, with 3-4 hours duration for each therapy session (total duration of therapy 32-33 hours, mean 31.5 hours). The conventional method group $(\mathrm{n}=7)$ received the same total duration of therapy, with the therapy schedule $3 \mathrm{x} /$ week for 3-4 weeks. In the end of the study, significant improvement of language ability (measured by the instrument of Communicative Activity $\log$ or CAL), was obtained only in the CIAT group. The difference of result between Pulvemuller and the researcher can be caused by several factors, one of which was due to unequal distribution of study subjects from the CIAT method and the conventional method groups. Pulvemuller did not differentiate study subjects and the type of aphasia. There were 2 ambidexter subjects in the CIAT group, and 1 subject in the conventional group. This can affect the homogenity of study subjects. Other factor that can affect the difference of the result was the difference of therapy duration on each session.

Several studies of aphasia therapy aimed to obtain the correlation between the intensity of speech therapy and positive change of language disorder of aphasia subjects. A metaanalysis study by Robey in 199833 found that positive effect of aphasia therapy was gained with the intensity of therapy duration 2 hours/week or more. He did not mention therapy method and also the period of aphasia therapy has to be given. Study of this speech therapy intensity support the result of this study. The CIAT method with therapy session duration of 5 hours/week for $5 \mathrm{x} /$ week frequency, resulted in the similar 
significant improvement of language ability and language production with the standard method with the therapy session duration of 3 hours/ week for $3 x /$ week frequency. Each therapy session has 1 hour duration for both group. Total of therapy duration for CIAT and standard method groups were the same that is 10 hours.

The intensity of speech therapy that affects the healing process of aphasia also found by Meinzer et al in 2004. Meinzer found that brain plasticity resulted from intensive speech therapy ( 30 hours for 2 weeks) in 28 study subjects with post stroke aphasia. Therapy schedule was $5 \mathrm{x} /$ week with 3 hours duration for each therapy session. EEG pre and post therapy were done to detect the Abnormal Slow Wave Activity Mapping (ASWAM). Meinzer found the decrease of ASWAM around the lesion post therapy, which shows that better healing process has achieved. ${ }^{40}$

The improvement that resulted from the speech therapy of aphasia subjects was measured not only from the change of ability to listen, to read, to speech, and to write; but also from the change of apparent behavior, affect, moral, and change in social contact ability. ${ }^{30}$

The CIAT method speech therapy was given $5 \mathrm{x} /$ week for 2 weeks. The standard method speech therapy was given $3 \mathrm{x} /$ week for 3 weeks. Both of these speech therapy methods gave the same total of therapy duration that was 10 hours, with 1 hour duration for each session. Although both of this speech therapy methods finally resulted in the similar language ability and language production, but the improvement of language ability and language production were obtained faster with the CIAT method. This was assumed as an advantage of the CIAT method to the standard method.

There were several limitation of this study, that the measuring instrument is subjective, as the Communicative Activity Log (CAL) results from the observation of the nearest family member pre and post treatment. Subjective instrument is really affected by psychological condition of family member during the CAL questionnaire admission, which can affect the validity of measurement result, on the assessment of language ability pre and post treatment, analysis was made from the total score of the whole items on the CAL instrument, the evaluation of study result pre and post treatment were done by the researcher, without blinding, which can result in measurement bias.

\section{CONCLUSIONS}

From this study results, it was concluded that the Constraint Induced Aphasia Therapy (CIAT) speech therapy method is effective to increase the language ability, the CIAT speech therapy method is effective to increase the language production, the standard speech therapy method is effective to increase the language ability, the standard speech therapy method is effective to increase the language production, there was no significant difference between the CIAT speech therapy method and standard speech therapy method to increase the language ability and language production in post stroke chronic Broca aphasia subjects.

The researcher suggests that it is needed to undergo a study that compare several therapy intensity such as frequency, each session duration, and speech therapy period to obtain the effect of speech therapy intensity to the language reorganizational process, is needed to indergo a study that analyze each item of the CAL instrument to measure the language ability, is needed to use a more objective instrument (EEG, PET, fMRI), to increase the validity of the instrument as well as the study results, is needed to use the blinding evaluation technique, to prevent the measurement bias, the CIAT speech therapy method is suggested to be given to subjects with chronic stroke Broca aphasia due to a faster achievement of language function improvementm compared to the standard method.

\section{REFERENCES}

1. Kusumoputro S. Afasia : Gangguan Berbahasa Hemisfer Kiri. In : Kusumoputro S, editor. Afasia : Gangguan Berbahasa. Edisi 1. Jakarta : Balai Penerbit FK UI ; 1992. p. $15-20$.

2. Gede Ngurah IGN. Diagnosis Topis. In : Gede Ngurah IGN, editor. Dasar - Dasar Ilmu Penyakit Saraf. Edisi 1. Surabaya 
: Balai Penerbit Universitas Airlangga ; 1990. p. $137-9$.

3. Setyono B. Peranan Bahasa dalam Kehidupan Manusia. Dalam : Ester M, editor. Terapi Wicara. Jakarta : Penerbit Buku Kedokteran EGC ; 2000. hal. 1 - 7.

4. Zigmond MJ, Bloom FE, Landis SC. Human Language. In : Zigmond MJ, Bloom FE, Landis SC, editors. Fundamental Neuroscience. 1st Edition. San Diego : Academic Press ; 1999. p. 1493 - 98.

5. Setyono B. Lebih Jauh tentang Afasia. In : Ester M, editor. Terapi Wicara. Jakarta : Penerbit Buku Kedokteran EGC ; 2000. p. $54-94$.

6. Dhamaperwira - Prins R. Penyebab Penyebab Afasia. Dalam : Dharmaperwira R, editor. Afasia : Deskripsi, Pemeriksaan, Penanganan. Edisi 2. Jakarta : Gaya Baru ; 2002. hal. 8 - 12 .

7. Pulvermuller F. Aphasia Therapy on Neuroscience Basis. Journal Aphasiology ; 2008, ; 22 (6); 563 - 99.

8. Kirshner HS. Aphasia . eMedicine Specialties Physical Medicine and Rehabilitation [online]. Updated February 11, 2009 [Cited 2009 June 20]. Available from : URL : http://www.emedicine.com.

9. Melfi RS. Communication Disorder. eMedicine Specialties Physical Medicine and Rehabilitation [online]. Updated April 23, 2008 [Cited 2009 June 20]. Available from : URL : http://www.emedicine.com.

10. Aphasia Statistic for US - Current [online]. [Cited 2009 July 8]. Available from : URL http://www.aphasia.com/wordpdf/1. BasicStatistic.pdf

11. Susilo H. Stroke : Pendekatan Segi Epidemiologi dan Faktor Resiko. Surabaya : Fakultas Kedokteran Universitas Airlangga / RSU Dr. Sutomo ; 2000.

12. Soebadi RD. Komunikasi, Bahasa, dan Wicara. Surabaya : Instalasi Rehabilitasi Medik RSU Dr.Sutomo ; 2000.

13. Setyono B. Neurofisiologi dan Mekanisme Wicara . In : Ester M, editor. Terapi Wicara. Jakarta : Penerbit Buku Kedokteran EGC ; 2000. p. $24-42$.

14. Dhamaperwira - Prins R. Bahasa dan Otak : Aspek - Aspek Linguistik. In
: Dharmaperwira R, editor. Afasia : Deskripsi, Pemeriksaan, Penanganan. Edisi 2. Jakarta : Gaya Baru ; 2002. p. 35 56.

15. Broca's Area, Wernicke's Area, and other Language Processing Areas in the Brain. Canadian Institute of Neurosciences, Mental Health and Addiction. [online]. [Cited 2009 June 13]. Available from : URL : http://thebrain.mcgill/ caflashdd_10d_10crd_10cr_land_10cr lan_html

16. Satterfield ST. Language and Attention. In : Satterfield ST, editor. Neuroscience : Exploring the Brain. First Edition. USA : Williams and Wilkins ; 1996. p. 581 -614.

17. Kusumoputro S. Gangguan Berbicara dan Berbahasa. In : Kusumoputro S, editor. Afasia : Gangguan Berbahasa. Edisi 1. Jakarta : Balai Penerbit FK UI ; 1992. p. $11-4$.

18. Dhamaperwira - Prins R. Gejala Gejala Linguistik. In : Dharmaperwira R, editor. Afasia : Deskripsi, Pemeriksaan, Penanganan. Edisi 2. Jakarta : Gaya Baru ; 2002. p. $57-62$.

19. Melfi RS. Communication Disorder. eMedicine Specialties Physical Medicine and Rehabilitation [online]. Updated April 23, 2008 [Cited 2009 June 20]. Available from : URL : http://www.emedicine.com.

20. Kusumoputro S. Daftar Pengertian Istilah. In : Kusumoputro S, editor. Afasia Gangguan Berbahasa. Edisi 1. Jakarta : Balai Penerbit FK UI ; 1992. p. 91 - 3.

21. Dhamaperwira - Prins R. Sindrom Sindrom Afasia. In : Dharmaperwira R, editor. Afasia : Deskripsi, Pemeriksaan, Penanganan. Edisi 2. Jakarta : Gaya Baru ; 2002. p. $57-62$.

22. Tan JC. Neurogenic Communication Disorder. In : Hurley R, editor. Practical Manual of Physical Medicine and Rehabilitation. First edition. St. Louis : Mosby Inc; 1998. p. 482 - 513.

23. Kusumoputro S. Klasifikasi Afasia. In : Kusumoputro S, editor. Afasia : Gangguan Berbahasa. Edisi 1. Jakarta : Balai Penerbit FK UI ; 1992. p. $21-8$.

24. Setyono B. Lebih Jauh Tentang Afasia. In 
: Ester M, editor. Terapi Wicara. Jakarta : Penerbit Buku Kedokteran EGC ; 2000. p. $54-94$

25. Basso A. Classification of Aphasia. In : Basso A, editor. Aphasia and Its Therapy. First edition. Milan : Oxford University Press ; 2003. p. $24-48$.

26. Spreen O, Risser AH. Clinical Bedside Examination. In : Spreen O, Risser AH, editors. Assessment of Aphasia. First Edition. Columbia : Oxford University Press ; 2003. p. $46-49$

27. Dhamaperwira - Prins R. Pemeriksaan Afasia Indonesia : TADIR dan IKF. In : Dharmaperwira R, editor. Afasia : Deskripsi, Pemeriksaan, Penanganan. Edisi 2. Jakarta : Gaya Baru ; 2002. p. 126 $-30$

28. Dharmaperwira - Prins R. Interpretasi Skor. In : Dharmaperwira R, editor. TADIR : Tes Afasia untuk Diagnosis, Informasi, Rehabilitasi. Balai Penerbit FK UI ; 2000. p. $27-29$

29. McCaffrey P. Neuropathologies of Language and Cognition [online]. [Cited 2009 July 12]. Available from : URL : http://www.csuchico.edu/ pmccaffery// syllabi

30. Kusumoputro S. Prinsip Terapi Gangguan Berbahasa. In : Kusumoputro S, editor. Afasia : Gangguan Berbahasa. Edisi 1. Jakarta : Balai Penerbit FK UI ; 1992. p. $72-80$

31. Dhamaperwira - Prins R. Cara - Cara Penanganan dan Program - Program yang Ada. In : Dharmaperwira R, editor. Afasia : Deskripsi, Pemeriksaan, Penanganan. Edisi 2. Jakarta : Gaya Baru ; 2002. p. 126 $-130$

32. Pulvermuller F, Neininger B, Elbert T, Mohr B, Rockstroh B, Koebbel P, Taub E. Constraint - Induced Therapy of Chronic Aphasia after Stroke. Stroke. 2001;32;1621 - 26.

33. Raymer A, Patterson JP, Cherney LR, Frymark T, Schooling T. Evidence - Base Systematic Review : Effect of Intensity of Treatment and Constraint - Induced Language Therapy for Individuals with Stroke Induced Aphasia. Journals of
Speech, Language, and Hearing

34. Meinzer M, Djuandja D, Barthel G, Elbert T, Rockstroh B. Long - Term Stability of Improved Language Function in Chronic Aphasia after Constraint - Aphasia Therapy. Stroke. 2005;36;1462 - 66 [online]. Cited 2009 June 15. Available from: URL: http://www.stroke.ahajournal. org/cgi/reprint/36/7/1462

35. Basso A. Efficacy of Aphasia. Therapy. In : Basso A, editor. Aphasia and Its Therapy. First edition. Milan : Oxford University Press ; 2003. p. $76-81$

36. Wertzs RT. The Role Therapy in Aphasia Therapy : Art or Science. In : Stuss DT, Winocur G, Robertson IA, editors. Cognitive Rehabilitation. First edition. New York : Cambridge University Press ; 1999. p. $265-71$.

37. Cherney LR, Patterson JP, Raymer A, Frymark T, Tracy S. Evidence Base Systematic Review : Effects of Intensity of Treatment and Constraint - Induced Language Therapy for Individual with Stroke - Induced Aphasia. Journals of Speech, Language, and Hearing Research. Vol. 51; 1282 - 99 [online]. Updated 2008 October. [Cited 2009 July 12]. Available from : URL : http://www.asha.org/pdf

38. Hatfield B, Miller D, Colles J, Gassaway J, Conroy B, Smout RJ. Characterizing Speech and Language Pathology Outcomes in Stroke Rehabilitation. Arch Phys Med Rehabil 2005;86(12 Suppl 2):S61-72 [online]. [Cited 2009 Oktober 11]. Available from : URL : http://www. aapmr.org

39. Maher LM, Schmadeke S. Comparison of Constraint Induced Language Therapy and Tradisional Therapy in the Rehabilitation of Chronic Aphasia [online]. [Cited 2010 March 29]. Available from : URL : http:// www.txsha.org/convention/pdf/

40. Anonim. Research on Intensif Therapy Outcomes : An Annotated Bibliograghy for the Last Ten Years. University of Michigan Aphasia Program [online]. [Cited 2010 March 29]. Available from : URL : http:// www.languageexpert.org 